\title{
A diatom functional-based approach to assess changing environmental conditions in temporary depressional wetlands
}

\author{
Luisa Riato ${ }^{a_{2 *}}$, Valentina Della Bellab ${ }^{b}$ Manel Leira ${ }^{c, d}$, Jonathan C. Taylor ${ }^{e, f}$, Paul J. \\ Oberholster $^{\mathrm{a}, \mathrm{g}}$ \\ a Department of Paraclinical Sciences, Faculty of Veterinary Science, University of Pretoria, Private Bag X04, \\ Onderstepoort, 0110, South Africa \\ ${ }^{b}$ Environmental Protection Agency of Umbria Region, ARPA UMBRIA, Via C. A. Dalla Chiesa 32, Terni, 05100, \\ Italy \\ ' Laboratório associado IDL, Faculdade de Ciências, Universidade de Lisboa, Campo Grande, Lisbon, 1749-016, \\ Portugal \\ ${ }^{d}$ Department of Botany, Biology Faculty, University of Santiago de Compostela, Campus Sur, Santiago de \\ Compostela, 15076, Spain \\ e School of Biological Sciences, North-West University, Private Bag X6001, Potchefstroom, North West \\ Province, 2520, South Africa \\ ${ }^{\mathrm{f}}$ South African Institute for Aquatic Biodiversity (SAIAB), Private Bag 1015, Grahamstown, 6140, South Africa \\ ${ }^{g}$ CSIR Natural Resources and The Environment, P.O. Box 320, Stellenbosch, 7599, South Africa \\ *Corresponding author. E-mail address: luisariato@gmail.com (L. Riato).
}

\begin{abstract}
Functional-based assessments to identify the effects of human-induced disturbances on diatom communities are increasingly used. However, information on the response of functional groups to natural disturbances in temporary depressional wetlands is limited although important for the development of temporary wetland biological assessments. We assessed how diatom life-form and ecological guilds responded to a seasonal hydrological and hydrochemical gradient in three least human-disturbed, temporary depressional wetlands. We assigned species to their respective life-form and ecological guild groups and compared metric composition along the gradient. Overall, temporal variability in alkalinity and ionic composition, essentially $\mathrm{Na}^{+}$, as well as hydrological factors, wetland depth and total relative evapotranspiration (ETo), were good predictors of diatom species and functional group composition. Low profile guilds dominated by pioneer life-forms showed the strongest relationship with higher disturbance levels (i.e. increasing $\mathrm{Na}^{+}$, alkalinity with a decrease in depth). Similarly, the planktonic guild and tube-living, rosette and adnate lifeforms dominated at higher disturbance levels whereas the high profile diatoms displayed the reverse trend. Our study shows the effectiveness of functional-based assessments beyond traditional species-based approaches for understanding and predicting community responses to temporal changes in environmental conditions. We also highlight the benefit of using both life-forms and ecological guilds where a broad set of metrics can enhance our
\end{abstract}


understanding of the mechanisms relating diatom composition to environmental stressors and provide signs of underlying ecological processes.

\title{
Keywords
}

\author{
Diatom \\ Life-form \\ Ecological guild \\ Ionic composition \\ Stressor \\ Temporal variability \\ Wetland
}

\section{Introduction}

Over the past decade there have been increasing efforts to develop biological monitoring tools to assess the condition of wetlands in human-modified landscapes (e.g., U.S. EPA, 2002). In South Africa, although biological assessment techniques for river health assessments are well established (e.g., Dickens and Graham, 2002; Taylor et al., 2005), in the case of wetlands there is currently no definitive, well-developed method for assessing ecological condition. The need to develop wetland condition assessment methods is urgent, particularly in wetland rich areas such as the Mpumalanga Province where mining has contributed to substantial loss and degradation of depressional wetlands (Riato et al., 2014). Such activities have modified the surface water hydrology and hydrochemistry of temporary depressional wetlands to varying degrees, and in some cases has resulted in extreme alkalization, salinisation and permanent inundation in what was previously a fresh, ephemeral system.

Numerous studies have demonstrated the robustness of diatoms as a tool to assess the ecological status of shallow lakes and wetlands (reviews in Bennion et al., 2010; Gaiser and Rühland, 2010). Diatom-based indices have been developed to assess pollution in shallow systems, particularly in Europe and North America (e.g., Kelly et al., 2007; Lane and Brown, 2007; Stenger-Kovács et al., 2007). However, diatom-indices require species level identification which can be challenging due to the large diversity of species included in these indices and the continual taxonomical changes (Gottschalk and Kahlert, 2012). The presence of species complexes that are difficult to identify using standard taxonomic techniques constitutes an additional problem particularly when the finest taxonomic accuracy is required by the quality indices (B-Béres et al., 2014). Moreover, the suitability of these indices can be limited, since most diatom indices derive their calculations based on species distributions found in specific regions and thus are not broadly applicable (Stenger-Kovács et al., 2007).

Rimet and Bouchez (2012a) demonstrated the robustness of using a broader taxonomic resolution in bioassessments. For this reason, the use of trait-derived functional groups may be useful for wetland assessments, particularly in South Africa, where wetland diatom flora is poorly described, thus, taxonomic information required for species-level identifications is 
lacking. Moreover, the use of functional groups is likely to provide a greater understanding of the role by which important environmental drivers influence diatom community structure (Lange et al., 2016).

The application of diatom functional groups (life-forms and ecological guilds), have become increasingly popular in ecological assessments over the past decade (Tapolczai et al., 2016), mostly in response to nutrient and pesticide contamination in lotic systems (e.g., Lavoie et al., 2010; Passy, 2007a,b; Rimet and Bouchez, 2011) and mesocosm experiments (e.g., Bayona et al., 2014; Morin et al., 2009). However, few studies have applied functional groups as a community measure for the ecological status in lakes (e.g., Gottschalk and Kahlert, 2012; Leira et al., 2015) and only one other study has proven their applicability in wetlands (nutrient rich ditches) (Goldenberg Vilar et al., 2014).

Given the urgent need to develop a bioassessment tool for assessing temporary depressional wetland conditions in the Mpumalanga Province, the main goal of this research was to determine whether diatom functional groups can be used as simple, effective and reliable indicators sensitive to changing environmental conditions in temporary depressional wetlands in the region. Establishing a reference condition of variation due to natural disturbances (e.g., seasonal fluctuations in both water-level and water chemistry) in temporary depressional wetlands using diatoms is necessary for further investigations of anthropogenic impacts. Thus, we examined three least human-disturbed temporary depressional wetlands during various stages of inundation in order to understand the natural effects of hydrological changes on the water chemical composition and its influence on functional groups. We focused on four aims: (a) to identify the most important physicochemical parameters influencing the structure of diatom species communities; (b) to compare those with the physico-chemical parameters structuring the functional groups; $(c)$ to examine temporal dynamics of functional groups along the hydrological and hydrochemical gradient; and (d) to identify the groups most responsive to changes along the gradient.

\section{Materials and methods}

\subsection{Study area}

The study area is located in the Bapsfontein region of the Gauteng Province of South Africa at an altitude of $1606 \mathrm{~m}$ asl. Three homogenous, temporary depressional wetlands (average depth $<2 \mathrm{~m}$ ) were selected in this area based on vegetation, conductivity, surrounding landuse and close proximity to one another (radius of $1 \mathrm{~km}$ ) (Fig. 1). The study sites (S1, S2 and S3) were sampled once a month from March 2011 (period of high inundation) to September 2012 (drying out period). Supplementary Data Appendix S1 summarises the physicochemical parameters distinguishing the sites S1, S2 and S3 (Table S1) and provides a detailed description of the local climatology. 


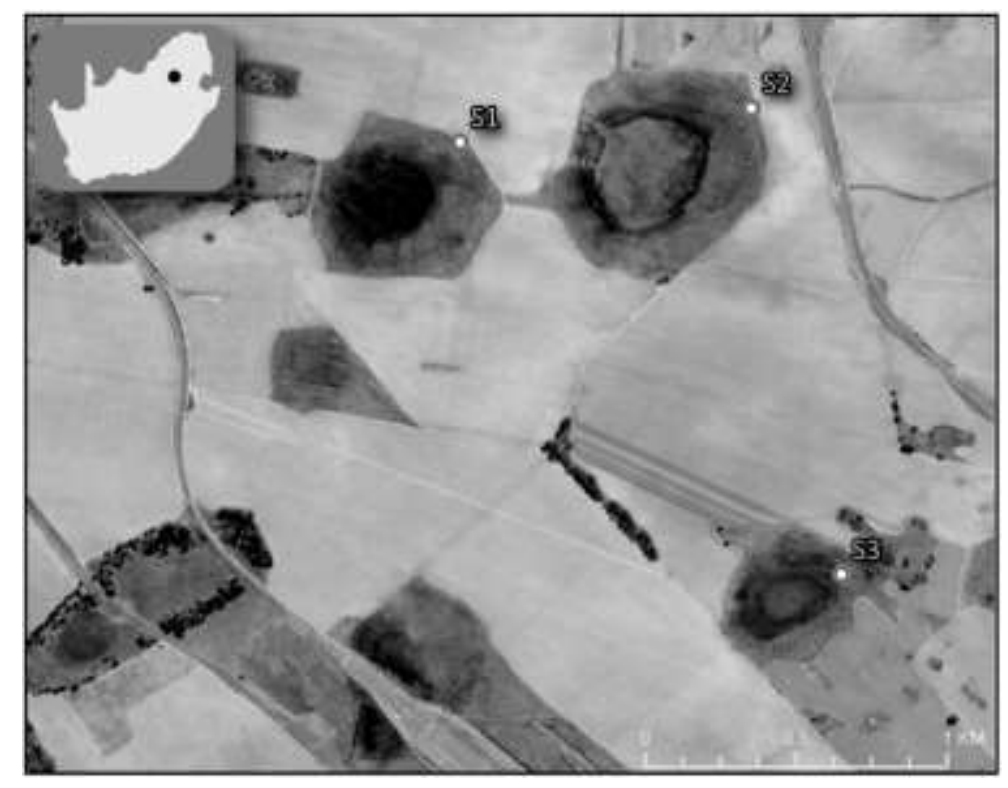

Fig. 1. Map of study area showing location of sites (S1, S2 and S3); inset shows study area location in South Africa.

\subsection{Sampling and laboratory methods}

We collected one sample of epiphytic diatoms from at least five submersed macrophyte stems of the same vegetation type (Leersia hexandra) at the deepest point in the basin centre (pelagic zone) at each site to ensure the comparability between water bodies as recommended by King et al. (2006). Macrophyte stems were snipped and placed into a zip lock bag with a small amount of distilled water; epiphytes were dislodged from all stems by shaking the samples for 2 min following Zimba and Hopson (1997). Samples were returned to the laboratory where they were acid cleaned and mounted on microscope slides. We counted and identified 400 valves to the lowest feasible taxonomic level using standard European diatom floras (e.g., Krammer and Lange-Bertalot, 1986-1991; Lange-Bertalot et al., 2001; Lange-Bertalot, 2000-2002), several papers on the Southern African flora by Cholnoky, Schoeman and Archibald (e.g., Schoeman and Archibald, 1976-1980), and books and recent papers on Gomphonema taxonomy (e.g., Reichardt, 2015; Reichardt and LangeBertalot, 1999; Rose and Cox, 2014).

Diatom taxa were assigned to two types of functional groups a), life-forms and b), ecological guilds, in accordance with Passy (2007a,b) and Rimet and Bouchez (2012b). The taxa assigned to the various life-form and ecological guild groups are listed in Table 1. A taxon can be assigned to more than one life-form group since certain taxa can have multiple lifeforms throughout its life-cycle (Rimet and Bouchez, 2012b). 
Table 1. Assignment of taxa to life-forms and ecological guilds following Passy $(2007 a, b)$ and Rimet and Bouchez (2012b).

\begin{tabular}{|c|c|c|}
\hline $\begin{array}{l}\text { Functional } \\
\text { groups }\end{array}$ & $\begin{array}{l}\text { Definition of functional group } \\
\text { classification }\end{array}$ & Taxa Assigned \\
\hline \multicolumn{3}{|l|}{ Life-forms } \\
\hline Mobile & $\begin{array}{l}\text { Free moving e.g. some species vertically } \\
\text { migrate into the sediments to acquire } \\
\text { nutrients }\end{array}$ & $\begin{array}{l}\text { Achnanthes, Achnanthidium, Brachysira, Caloneis, } \\
\text { Diadesmis, Encyonema, Eolimna, Eunotia, Frustulia, } \\
\text { Gomphonema, Luticola, Mayamaea, Navicula, } \\
\text { Nitzschia, Rhopalodia, Sellaphora, Stauroneis }\end{array}$ \\
\hline Pioneer & $\begin{array}{l}\text { Species colonise bare substrates faster } \\
\text { than other species }\end{array}$ & $\begin{array}{l}\text { Achnanthidium minutissima var. minutissima, A. } \\
\text { minutissima var. affinis, A. saprophilum }\end{array}$ \\
\hline Tube-living & $\begin{array}{l}\text { Species live in mucous substance within } \\
\text { which they can move freely }\end{array}$ & Frustulia, Encyonema mesianum \\
\hline $\begin{array}{l}\text { Rosette } \\
\text { colony }\end{array}$ & $\begin{array}{l}\text { Species attached to substrate by a short } \\
\text { stalk at one pole; colonies look fan- } \\
\text { shaped }\end{array}$ & Ulnaria acus \\
\hline $\begin{array}{l}\text { Ribbon } \\
\text { colony }\end{array}$ & $\begin{array}{l}\text { Species attached to one another either } \\
\text { by interlocking spines or by a layer of } \\
\text { mucous on their valve face, forming } \\
\text { long, ribbon-like colonies }\end{array}$ & Eunotia bilunaris, Eunotia minor, Eunotia pectinalis \\
\hline Pedunculate & $\begin{array}{l}\text { Species grows upright to substrate, } \\
\text { attached either by a mucilage pad or by } \\
\text { a stalk }\end{array}$ & $\begin{array}{l}\text { Achnanthes, Achnanthidium, Fragilaria, Ulnaria, } \\
\text { Gomphonema }\end{array}$ \\
\hline Adnate & $\begin{array}{l}\text { Species grows parallel to substrate, } \\
\text { attached by their valve face }\end{array}$ & Rhopalodia gibba \\
\hline \multicolumn{3}{|c|}{ Ecological guilds } \\
\hline High-profile & $\begin{array}{l}\text { Species of tall stature, including erect, } \\
\text { filamentous, branched, chain-forming, } \\
\text { tube-forming, pedunculate, and colonial } \\
\text { centrics }\end{array}$ & $\begin{array}{l}\text { Diadesmis, Encyonema mesianum, Eunotia, Fragilaria, } \\
\text { Ulnaria Gomphonema }\end{array}$ \\
\hline Low-profile & $\begin{array}{l}\text { Species of short stature, including } \\
\text { prostrate, adnate, small erect, solitary } \\
\text { centrics, slow-moving species }\end{array}$ & Achnanthes, Achnanthidium, Brachysira \\
\hline Motile & Fast-moving species & $\begin{array}{l}\text { Caloneis, Eolimna, Luticola, Mayamaea, Navicula, } \\
\text { Nitzschia, Rhopalodia, Sellaphora, Stauroneis }\end{array}$ \\
\hline Planktonic & Solitary or colonial centrics, pennates & $\begin{array}{l}\text { Cyclotella meneghiniana, Fragilaria tenera, Ulnaria } \\
\text { acus, Nitzschia acicularis }\end{array}$ \\
\hline
\end{tabular}

We adapted the functional groups to accommodate taxa identified in our study which were not mentioned in Rimet and Bouchez (2012b). A total of sixty-three diatom samples were analysed and 83 taxa were identified. We examined the seasonal patterns of the different functional groups based on their relative abundances in order to develop a more comprehensive understanding of temporal changes in biofilm structure and provide insight into the major parameters structuring group composition.

We sampled chemical and physical parameters at the same location and time as the diatom sampling. Water samples $(1 \mathrm{~L})$ were collected in an acid-cleaned, high-density polyethylene bottle and kept on ice during transportation to the laboratory. Samples were analysed for concentrations of biological oxygen demand (BOD), $\mathrm{NH}_{4}{ }^{+}$, total Kjeldahl nitrogen (TKN), 
$\mathrm{NO}_{3}{ }^{-}, \mathrm{NO}_{2}{ }^{-}, \mathrm{P}, \mathrm{PO}_{4}{ }^{2-}$, total phosphate (TP) $, \mathrm{Ca}^{2+}, \mathrm{Mg}^{2+}, \mathrm{Na}^{+}, \mathrm{K}^{+}, \mathrm{Cl}^{-}, \mathrm{SO}_{4}{ }^{2-}$, dissolved organic carbon (DOC), turbidity, total suspended solids (TSS), alkalinity and conductivity. Analysis was conducted by Waterlab (Pty.) Ltd. laboratory in Pretoria following standard procedures (APHA, 1998). Temperature, $\mathrm{pH}$, dissolved oxygen (DO) and water depth were measured in the field.

We included total relative evapotranspiration (ETo) data in the analysis to represent the seasonal (summer-winter) gradient. ETo data, calculated from hourly data using the FAO-56 Penman-Monteith method (Zotarelli et al., 2010), was collected from a weather station owned by the Agricultural Research Council located $6 \mathrm{~km}$ from the study sites. For each sampling month, we used the monthly ETo which was calculated as the mean of the daily ETo values for the sampling month.

\subsection{Data analysis}

We used CANOCO 4.5's (ter Braak and Šmilauer, 2002) redundancy analyses (RDA) to examine relations of physico-chemical parameters to diatom compositional structure at species and functional group level. Inclusion of physico-chemical parameters in the final analysis was based on eliminating collinear variables with a high variance inflation factor (VIF > 10) (ter Braak and Šmilauer, 1998). We applied step-wise forward selection to select a final set of physico-chemical parameters that related best to the diatom species and functional group composition (ter Braak and Šmilauer, 1998). We calculated Spearman's rank correlations using SAS 9.4 (SAS Institute, Cary NC) and performed a Bonferroni-Holm correction for multiple comparisons (Holm, 1979) to determine which functional groups were sensitive to the most important parameters structuring the diatom communities.

Diatom species and functional group abundance was square root transformed and physicochemical parameters not meeting normality assumptions were log transformed in order to normalise distributions and reduce skewness.

\section{Results}

\subsection{Functional group composition}

The most common functional groups which contributed up to $50 \%$ of the counts belonged to the mobile life-form (37\%), the high profile (17\%) and motile guild (17\%), and the pedunculate life-form (13\%). Mobile diatoms were comprised of Nitzschia acidoclinata (31\% of all mobile valves counted), followed by Encyonema mesianum (13\%), Nitzschia gracilis (9\%), Eunotia bilunaris (8\%) and Achnanthidium minutissimum (7\%). Motile diatoms were dominated by Nitzschia acidoclinata (67\%), Nitzschia gracilis (19\%) and Nitzschia fruiticosa (7\%). High profile diatoms were mostly comprised of Encyonema mesianum (28\%), Eunotia bilunaris (17\%), Gomphonema aff. angustatum (14\%), Gomphonema parvulum (10\%) and Gomphonema auritum (9\%). The most abundant pedunculates were $A$. minutissimum (20\%), G. aff. angustatum (18\%), G. parvulum (12\%) and G. auritum (11\%). 


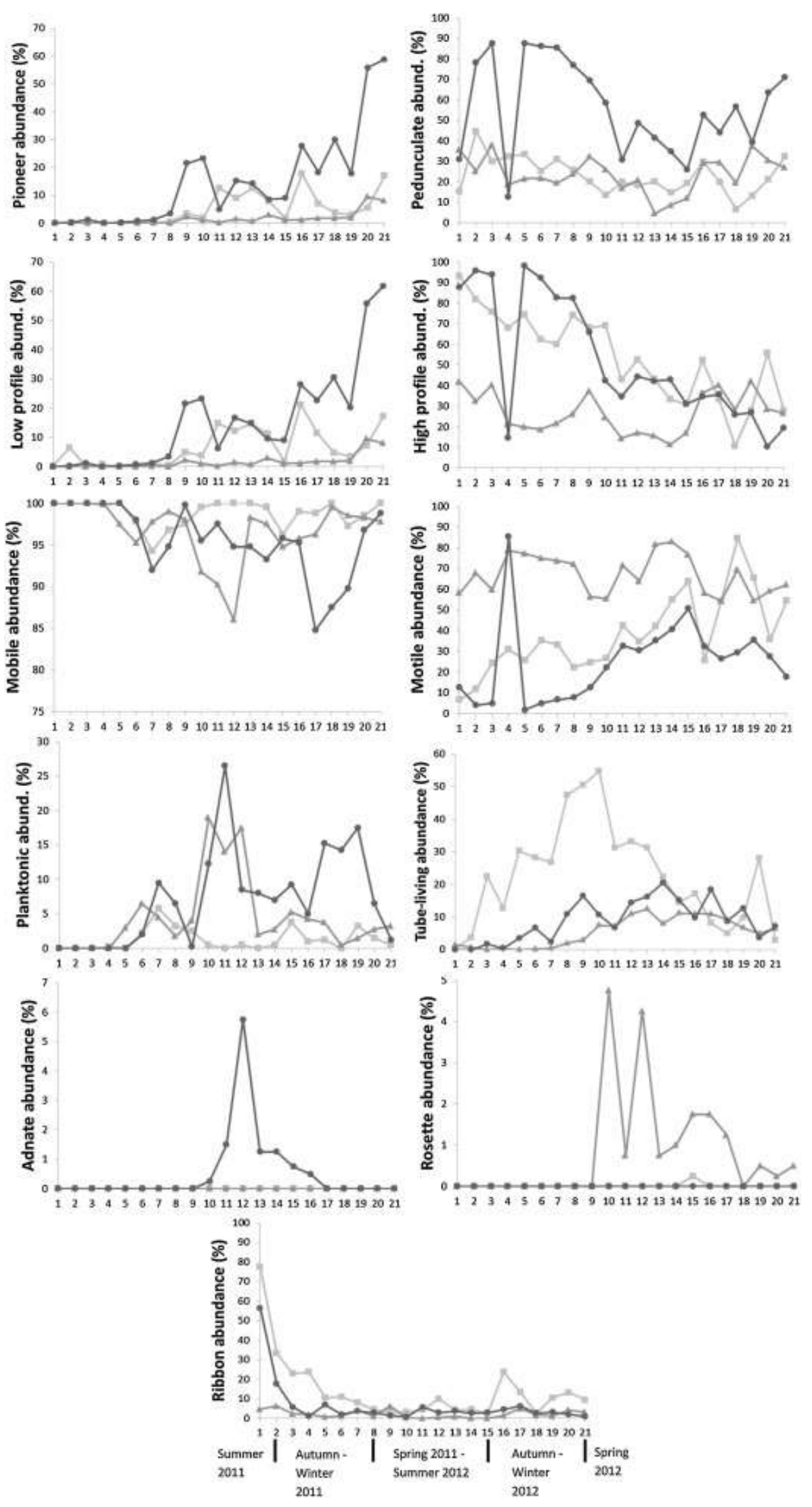

Fig. 2. Life-forms and ecological guilds relative abundances calculated (\% out of 400 valves/slide) for each sampling month for site S1 (square), S2 (triangle) and S3 (circle). The number refers to each consecutive sampling month. Month 1: end of summer 2011; 2 - 7: autumn-winter 2011; 8 - 14: spring-summer 20112012; 15-20: autumn-winter 2012; 21: spring 2012. 


\subsection{Seasonal patterns in functional group composition}

Fig. 2 displays the seasonal patterns of the different life-forms and ecological guilds in the three study sites. There was a distinct succession between the high profile guild and the low and motile profile guild, particularly at sites S1 and S3. At the end of summer 2011, the high profile guild abundance steadily declined and was gradually replaced by the low profile and motile guild until the end of sampling. This was not the case for site S2, where the motile guild dominated the biomass throughout the study. The pioneer life-form followed similar seasonal patterns to that of the low profile guild for the reason that both groups were largely dominated by Achnanthidium minutissimum.

Site S3 was dominated by Gomphonema taxa which were assigned to both the high profile guild and the pedunculate life-form. For this reason, seasonal patterns were comparable for these two groups at this site.

Albeit fairly uncommon, the rosette life-form comprised of Ulnaria acus at site S2 only, and the adnate life-form, represented by Rhopalodia gibba at S3, displayed similar abundance patterns, where growth started in summer 2011 and reached peak biomass during the summer season.

The ribbon life-form, consisting of Eunotia taxa, rapidly declined at the end of summer 2011 and thereafter occurred infrequently throughout the study. The mobile guild mostly dominated the biomass throughout the study at all sites. However, an important decline in mobile abundance observed during winter 2011 for all sites, summer 2012 for S2 and autumn 2012 for S3, coincided with an increase in planktonic diatoms mostly dominated by Fragilaria tenera.

During autumn and winter 2011 until mid-summer 2012, the abundance of tube-living lifeform diatoms, dominated by Encyonema mesianum, showed an important increase in abundance at site S1. E. mesianum then rapidly decreased until mid-winter 2012, when this taxon started to re-establish. The proportion of tube-living life-forms was comparatively lower at sites S2 and S3.

\subsection{Environmental predictors}

The relative importance of the physico-chemical parameters on the structure of the diatom communities were assessed using RDA for the species and functional group composition. Fig. 3 shows the parameters representing the highest correlation with the first two axes of the RDA. The most important structuring parameters for both diatom species and functional group composition were $\mathrm{Na}+$ and alkalinity. Likewise, $\mathrm{Cl}-$, depth and ETo were the secondary most prominent drivers structuring diatom communities for both species and functional groups (Fig. 3). RDA using Na+, alkalinity, $\mathrm{Cl}-$, depth and ETo explained $27 \%$ and $66 \%$ of the variation for species and functional groups, respectively; all axes were significant ( $P<0.01$, 999 Monte Carlo permutations). The first two axes explained $20.5 \%$ of the variation in diatom species composition (Fig. 3a), and $60.9 \%$ of the variation in functional group composition (Fig. 3b). Redundancy coefficients for species and functional groups respectively indicated that the first axis was associated with alkalinity $(0.64,-0.57)$ and ETo 
$(0.30,-0.29)$, attributed to seasonal changes. The second axis was affiliated with $\mathrm{Na}+(-0.84$, $-0.54)$ and $\mathrm{Cl}-(-0.39,-0.47)$ which reflect the marine origins of the bedrocks. In the species RDA, the second axis was influenced by depth $(0.45)$ whilst in the functional group RDA, the first axis was correlated with depth (0.43).
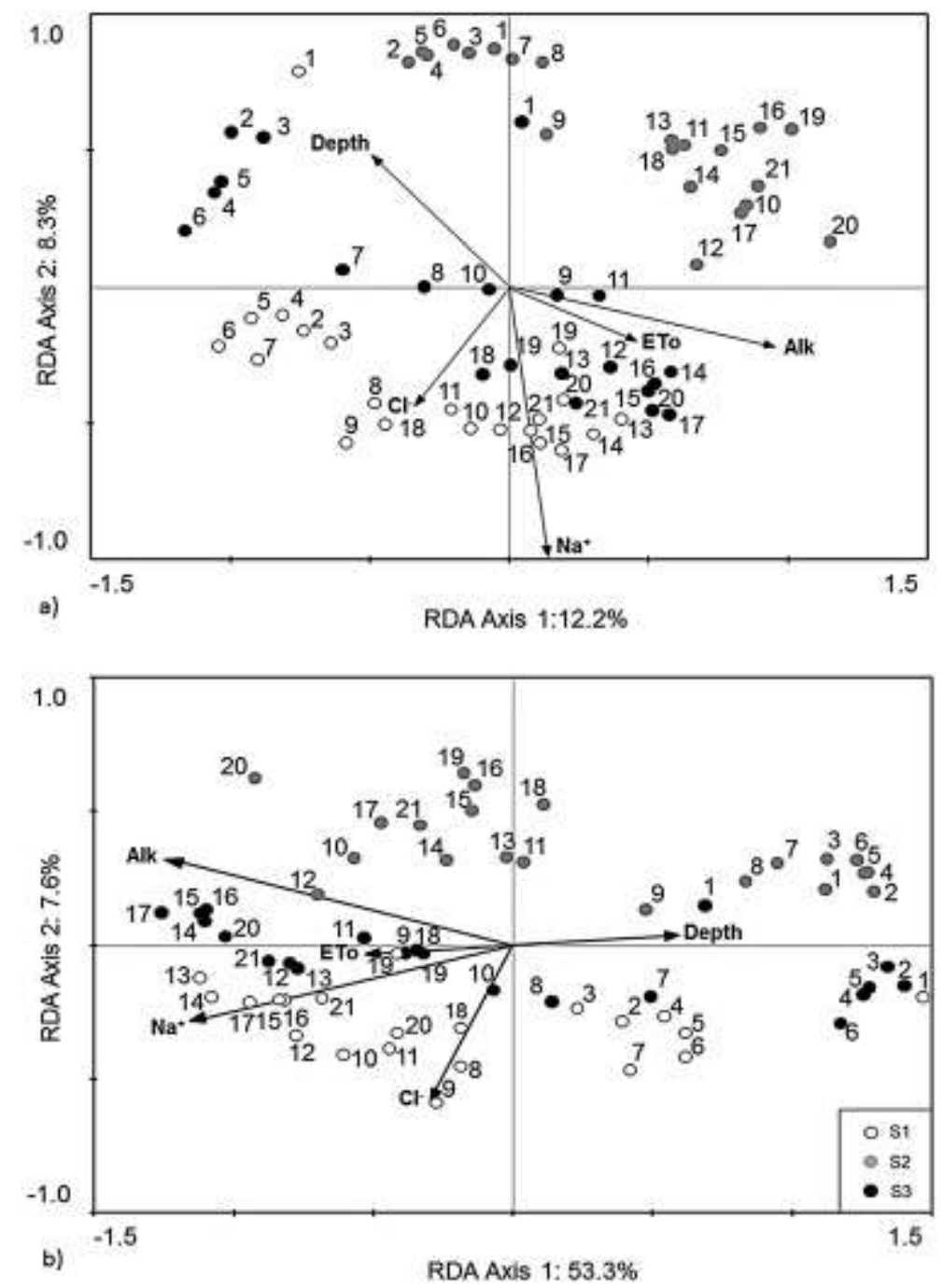

Fig. 3. Redundancy analyses (RDA) ordination plots for (a) species composition and (b) functional group composition (life-forms and ecological guilds) and significantly correlated physico-chemical parameters. ETo represents the monthly mean total relative evapotranspiration. Noted on the axis is the percent variance explained by each axis. The circles represent the 3 study sites; S1 (open circle), S2 (grey circle) and S3 (black circle). The number refers to each consecutive sampling month.

At the beginning of sampling in March 2011, the diatom communities for both species and functional groups in all three sites were located in the upper quadrant of the plot which corresponded to the high water-levels recorded at each site in the first month of sampling (Fig. 3a,b). Over the course of sampling, S1, S2 and S3 species and functional group assemblages responded initially to water-level changes, followed by fluctuations in ionic concentration (alkalinity) and/or composition $\left(\mathrm{Na}^{+}, \mathrm{Cl}^{-}\right)$.

Table 2 shows the significant relationships between the diatom functional groups and the five important environmental parameters based on Spearman's rank correlation and the 
Bonferroni-Holm correction. The pioneer life-form and low profile guild correlated significantly with three physico-chemical parameters and showed the strongest correlations compared to other functional groups (Table 2). They responded to higher concentrations of alkalinity and $\mathrm{Na}^{+}$, in accordance with a decrease in depth. Similarly, $\mathrm{Na}^{+}$had a highly positive effect on the abundance of tube-living life-forms with a decrease in depth. However, the tube-living diatoms did not show significant correlations with depth after the Bonferroni-Holm correction.

Table 2. Spearman's rank correlation coefficients between diatom life-forms and ecological guilds and the five important physico-chemical parameters. Significance of each comparison is indicated by *P $\leq 0.05$ and ** $P \leq 0.01$. Significant correlations following the sequential Bonferroni-Holm method at a cut-off point of $P=0.05$ are printed in bold.

\begin{tabular}{|c|c|c|c|c|c|c|c|c|c|}
\hline & Depth & & ETo & & Alk & & $\mathrm{Na}^{+}$ & & $\mathrm{Cl}^{-}$ \\
\hline Mobile & 0.12 & & -0.20 & & -0.35 & $* *$ & -0.12 & & 0.17 \\
\hline Pioneer & -0.63 & & 0.37 & $* *$ & 0.68 & & 0.70 & & 0.30 \\
\hline Tube-living & -0.39 & $* *$ & 0.34 & $* *$ & 0.21 & & 0.62 & & 0.25 \\
\hline Rossette & 0.15 & & 0.41 & & 0.52 & & 0.13 & & 0.11 \\
\hline Ribbon & -0.12 & & -0.17 & & -0.28 & $*$ & 0.26 & $*$ & 0.23 \\
\hline Pedunculate & 0.22 & & -0.09 & & -0.04 & & 0.03 & & 0.31 \\
\hline Adnate & 0.37 & $* *$ & 0.51 & & 0.45 & & 0.42 & & 0.36 \\
\hline High Profile & 0.17 & & 0.03 & & -0.47 & & 0.02 & & 0.28 \\
\hline Low Profile & -0.64 & & 0.34 & $* *$ & 0.63 & & 0.75 & & 0.33 \\
\hline Motile & -0.03 & & -0.09 & & 0.25 & $*$ & -0.24 & & -0.33 \\
\hline Planktonic & -0.11 & & 0.30 & $*$ & 0.43 & & 0.15 & & -0.02 \\
\hline
\end{tabular}

The adnate life-form correlated significantly with three parameters, alkalinity, $\mathrm{Na}^{+}$and ETo although this group was not as sensitive to alkalinity and $\mathrm{Na}^{+}$as the pioneer life-form (Table 2). Likewise, the rosette life-form showed a significant and similar sensitivity to fluctuations in alkalinity and ETo. Alkalinity also had a significant positive effect on the abundance of planktonic guild diatoms whereas the high profile diatoms displayed the reverse trend. No functional group was significantly correlated to chloride after sequential Bonferroni correction. The mobile life-form and motile guild groups did not show any significant correlations with the five parameters after correction.

\section{Discussion}

\subsection{Taxonomical challenges and benefits of using diatom functional groups}

A prominent feature of this wetland dataset is the abundance and variety of Gomphonema taxa, some of which belong to the species complexes of Gomphonema parvulum, Gomphonema exilissimum and Gomphonema angustatum or in many cases, were unidentifiable. Species complexes can be a salient issue when using classical species-based diatom bioassessment tools which require identification to species or subspecies taxonomic level for correct implementation (Lane, 2007). Blanco et al. (2004) highlighted such limitations when applying indices such as the BDI (Biological Diatom Index) in a Mediterranean shallow lake where Gomphonema species complexes dominated. 
Alternatively, using life-forms and ecological guilds where genus level identification is sufficient for the allocation of these metrics (Rimet and Bouchez, 2012b), would overcome such taxonomical challenges. Moreover, the use of a higher taxonomical group would reduce the effort in taxonomic identification, thus providing a more time and cost effective method; an important feature of environmental assessment for resource managers.

Contrary to Rimet and Bouchez (2012b), a few investigators (e.g., Lange et al., 2016; Passy, 2007a) have highlighted the potential loss of some ecological information when using genus level taxonomy to assign taxa to functional groups. An ecological guild is not based on a single trait but combines multiple traits which include "life-form, attachment mechanism and motility" (Lange et al., 2016). Species which belong to the same genus group can have different traits and therefore classification of taxa into guilds may require species level identification. However, these limitations did not appear to affect our results most likely because many of the unidentifiable taxa in our dataset were of the Gomphonema genus, in which all taxa of this genus are classified as high profile diatoms with pedunculate, mobile life-forms.

\subsection{Most sensitive functional groups to environmental changes in temporal wetlands}

A strong correlation was observed between patterns of community composition using species and functional groups in this temporary depressional wetland dataset. Consistent with other studies (e.g., Goldenberg Vilar et al., 2014), the functional rather than speciesbased approach explained more of the variation in diatom community composition, most likely because diatom functional groups incorporate species that have similar response to environmental conditions and available resources. Diatom functional groups have been reported as effective indicators of temporally changing stressors and disturbances in streams (Stenger-Kovács et al., 2013), as was observed in our study. Temporal changes in the concentration and composition of major ions, essentially $\mathrm{Na}^{+}$, as well as water depth, not only gave rise to pronounced taxonomic shifts in diatom assemblages but also produced distinct shifts in the composition of the diatoms' ecological guilds and life-form groups. Major ion dominance and water depth have already been identified as important drivers structuring diatom communities in lentic systems (e.g., Blinn, 1993; Gasse et al., 1995; Gregory-Eaves et al., 1999; Köster et al., 2004).

The low profile guild, mostly comprised of the pioneer life-form species, Achnanthidium minutissimum, showed a significant positive relationship with alkalinity and $\mathrm{Na}^{+}$, while depth had a negative effect. A decrease in water-level can cause sediment resuspension in shallow lakes which can decrease the total nitrogen to total phosphorus (TN:TP) ratio in the water, since the ratio is typically lower in the surface sediment than in the water (Niemistö et al., 2008). Sediment resuspension and redistribution can also reduce the light conditions of the water column and as a result cause considerable depletion in colonisable substrate (Leira et al., 2015). Moreover, in closed-basin systems such as these temporary depressional wetlands, a decrease in depth as a result of seasonal variations in the balance between precipitation inputs and potential evaporation losses can give rise to the concentration of wetland water, and in turn may cause a significant increase in ionic concentration and composition (Saros and Fritz, 2000). 
Low profile $A$. minutissimum has been widely documented as an early coloniser resistant to various disturbances including extreme fluctuations in lake water-level (Leira et al., 2015), low light exposure and low nutrient conditions in lakes (Gottschalk and Kahlert, 2012) and shear stress (Peterson and Stevenson, 1992). In addition, $A$. minutissimum has been reported as an alkaliphilous species with a high affinity for $\mathrm{Na}^{+}$-dominated lakes (Gasse, 1986; Vázquez and Caballero, 2013), conditions which other species may find intolerable. Bhattacharyya and Volcani (1980) demonstrated an increase in silicate (nutrient) uptake by a marine diatom species when a $\mathrm{Na}^{+}$gradient was imposed across the cell membrane. Our results verify that the influence of $\mathrm{Na}^{+}$on diatom community structure is undoubtedly different from the effect of other ions. However, mechanisms accountable for the higher or lower affinity of freshwater diatoms to $\mathrm{Na}^{+}$as well as ionic concentration are as yet undetermined (Potapova and Charles, 2003a,b).

Similar to the pioneer diatoms, the proportion of the adnate diatom Rhopalodia gibba of the motile guild also significantly increased with increasing alkalinity, $\mathrm{Na}^{+}$and total relative evapotranspiration (ETo). $R$. gibba is well adapted to waters with elevated ionic content and alkalinity such as the boreal alkaline ponds in Alberta, Canada, which are high in sulphates (Timoney et al., 1997). Irradiance may be reduced as a result of a decrease in water-level and an increase in sediment resuspension, thus providing suitable conditions for epiphytic motile diatoms capable of migrating.

This result is in agreement with those reported in a temporally changing Hungarian stream where motile guilds were resistant to disturbances such as lower irradiance during flooding through their ability to migrate to the surface layer of the biofilm and maintain access to light (Stenger-Kovács et al., 2013).

Studies have described intracellular spheroid bodies within $R$. gibba, and these bodies have been hypothesised as nitrogen-fixing symbionts which are able to provide nitrogen to their host diatom (Prechtl, 2004). Prechtl (2004) predicted that the genome of the spheroid bodies are closely related to that of, Cyanothece sp., a cyanobacterium species. During resuspension in shallow eutrophic lakes, the low $\mathrm{N}$ to $\mathrm{P}$ ratios can favour nitrogen-fixing cyanobacteria over other algal assemblages (Niemistö et al., 2008). It is thus conceivable that the low water-level and high sediment resuspension in our wetlands could promote the growth of $R$. gibba which harbour these nitrogen-fixing symbionts.

Abundance of tube-living tubule diatoms, dominated by Encyonema mesianum, showed a significant positive correlation to $\mathrm{Na}^{+}$. The Encyonema genus is generally regarded as sensitive to environmental stressors such as high organic loads and nutrient enrichment (e.g., Berthon et al., 2011; Leira et al., 2009; Rumeau and Coste, 1988). Nevertheless, Rimet and Bouchez (2011) observed an increase in tube-living diatoms under intense chemical disturbances in pesticide-contaminated mesocosms. Rimet and Bouchez (2011) hypothesised that the tubule, composed of exopolysaccharide matrices, may protect the cells living within from dissolved chemicals in the water, which could explain their resistance to increasing $\mathrm{Na}^{+}$concentrations here. The matrices include carbohydrates containing negatively charged groups which bind to positively charged cations, reducing the cation income into the cell (Masmoudi et al., 2013). 
At site S1, tubule diatoms showed a rapid increase in abundance during autumn-winter 2011 followed by an abrupt decline in mid-summer 2012. S1 had the shortest hydroperiod of all three sites; thus, any disturbances such as an increase in $\mathrm{Na}^{+}$concentration could have an important influence on diatom composition. Variation in major ions is more acute in smaller wetlands than in larger wetlands because smaller wetlands are more affected by changes in the hydrologic budget which have the capacity to change wetland water-level and water chemistry (Caramujo and Boavida, 2010). The maximum and mean $\mathrm{Na}^{+}$ concentrations were substantially higher at S1 compared to S2 and S3 (Supplementary Table S1), hence tubule diatoms could conceivably be subject to more competition from other species at $\mathrm{S} 2$ and $\mathrm{S} 3$ in a lower $\mathrm{Na}^{+}$environment. This may explain why the proportion of tube-living life-forms was comparatively lower at S2 and S3 although we have no direct evidence and further investigations are required to verify this.

Diatoms of the planktonic guild, mostly Fragilaria tenera, and the rosette diatom Ulnaria acus (planktonic guild) were significantly correlated to increasing alkalinity. The rosette lifeform was also positively related to ETo. Planktonic diatoms can attach to the biofilm but understanding of their dynamics within the complex biofilm structure and how they respond to temporally changing conditions in stagnant waters is limited (Goldenberg Vilar et al., 2014). The abundance of planktonic diatoms has been correlated to high turbidity and low light conditions (B-Béres et al., 2014; Rimet and Bouchez, 2012b). Interestingly, there were clear successional phases observed at each site where the planktonic guild replaced the mobile life-forms although these successions did not always occur simultaneously at all three sites. This may be attributed to differences in physical characteristics among the sites (e.g., basin area and depth; see Supplementary Data Appendix S1), that may affect their hydrology, and in turn, have a major influence on their water chemistry and ecological processes (e.g., rate of organic matter decomposition and carbon capture) (Brooks, 2009). F. tenera, an opportunistic r-strategist species (i.e. species whose ecology is defined by a high growth rate, $r$ ) can dominate phytoplankton communities (bloom) when conditions are favourable in the surface waters e.g., high light penetration through the water column and high nutrient availability (Black, 2008). We hypothesise that a proportion of seasonal blooms of $F$. tenera in the water column may have been trapped in the biofilm which could perhaps explain these bursts in planktonic abundance throughout the study.

In contrast to the rosette and adnate life-forms, and the low profile and planktonic guilds, the high profile guild, mostly comprised of the genus Gomphonema (pedunculate diatoms) were significantly reduced by higher alkalinity content. These findings corroborate the results of other studies in which the high profile diatoms were the most sensitive groups to disturbances (e.g., water-level changes: Leira et al., 2015; elevated ionic content and flooding: Stenger-Kovács et al., 2013; B-Béres et al., 2014; low light and nutrient availability: Berthon et al., 2011; Lange et al., 2011; grazing pressure: Luttenton et al., 1986). As to why the high profile guild was negatively related to alkalinity is uncertain. It is possible that some variable highly correlated with ionic concentration is the driver of these functional group shifts in diatom communities, rather than ionic concentration itself. For example, Stokes (1986) found grazing pressure to decline with a decrease in $\mathrm{pH}$. Stalked epiphytes are more prone to loss from grazing as they are positioned high within the biofilm which is more susceptible to grazing (Agrawal, 1999; Rimet et al., 2009), which could explain their preference for lower alkaline conditions here. On the contrary, low profile diatoms which 
have greater attachment strength, are strong competitors in these environments as they have good resistance to high grazing pressure (Goldenberg Vilar et al., 2014).

At the end of summer 2011, there was a gradual decline in high profile diatoms at sites S1 and S3, which were steadily replaced by the low profile (e.g., A. minutissimum) and motile guild (e.g., prevalent Nitzschia acidoclinata) until the end of sampling. In contrast, at S2, the motile diatoms, Nitzschia acidoclinata and Nitzschia gracilis generally dominated the biofilm throughout the study. S2 was substantially $\mathrm{Ca}^{2+}$ richer and $\mathrm{Na}^{+}$poorer compared to the other two sites (Supplementary Data Table S1). Studies have demonstrated the importance of $\mathrm{Ca}^{2+}$ in diatom assemblage structure (e.g., Blinn, 1993; Patrick and Reimer, 1966; Potapova and Charles, 2003a,b). $\mathrm{Ca}^{2+}$ is important for growth and motility where motile taxa such as the Nitzschia genus utilise this ion for regulation of locomotion (Cohn and Disparti, 1994). In addition, Potapova and Charles $(2003 a, b)$ found that many diatoms with relatively high optima for base cations (such as $\mathrm{Ca}^{+}$) had low optima for $\mathrm{Na}^{+}$; from which they concluded that the ratio of monovalent to divalent cations was a major factor influencing diatom species composition (see also, Gasse et al., 1983). It is possible that the proportion of individual cations and anions may have had a strong influence on the abundance of motile diatoms at this site.

\section{Conclusion}

Our study demonstrates the sensitivity of life-forms and ecological guilds to seasonal changes along a hydrological and hydrochemical gradient in temporary depressional wetlands without compromising any loss of ecological information when using a broader taxonomic resolution. Low profile guilds dominated by pioneer life-forms showed the strongest relationship with higher disturbance levels (i.e. increasing $\mathrm{Na}^{+}$, alkalinity with a decrease in depth). Similarly, the planktonic guild and tube-living, rosette and adnate lifeforms dominated at higher disturbance levels whereas the high profile diatoms displayed the reverse trend.

The strong ecological responses of life-forms and guilds to changing environmental conditions observed in this study suggests that with further research, diatom functional groups may be used in bioassessments and monitoring in the region, where wetland species taxonomy is poorly described. The use of functional groups may also be advantageous where budgets are limited but a reliable ecological status of the wetlands is still required, given its time and cost effective approach.

Nevertheless, we highlight the importance of complementing functional groups with traditional species-based diatom assessment tools, even if species taxonomy is uncertain. The relationship between the taxonomical and functional composition using a broad set of traits can provide insight into the mechanisms influencing diatom community structure and further our understanding of depressional wetland functioning. Numerous functionalrelated studies have focused solely on ecological guilds and their response to environmental conditions in wetlands (Goldenberg Vilar et al., 2014), lakes (Gottschalk and Kahlert, 2012; Leira et al., 2015), rivers (B-Béres et al., 2014) streams (Passy, 2007a; Stenger-Kovács et al., 2013) and mesocosm experiments (Lange et al., 2011; Passy and Larson, 2011). However, 
we advocate the inclusion of life-forms which provide additional information on the species' capacity to obtain resources and tolerate disturbance.

The functional groups which were good indicators of environmental changes and the important environmental variables identified can serve as a reference condition for further research on assessing impairment and restoration in similar wetlands subjected to environmental modifications. We recommend investigations of a variety of depressional wetlands in the region that encompass a wide range of disturbances, both natural and human-induced, in order to refine our findings and determine whether a simplified functional-based approach can discriminate between natural and anthropogenic disturbances.

\section{Acknowledgements}

Luisa Riato was supported by a Coaltech Research Association Research Fellowship. We thank Waterlab (Pty) Ltd. who covered water analysis expenses; Scott Driskill who provided cartographic support and Bradley Reynolds and Wetland Consulting Services (Pty) Ltd. who assisted with data collection. We also thank the anonymous reviewers for the comments and suggestions on the manuscript. J.C. Taylor is the recipient of South African National Research Foundation (NRF) incentive funding. Any opinions, findings and conclusions or recommendations expressed in this material are those of the author(s) and therefore the NRF does not accept any liability in regard thereto.

\section{References}

American Public Health Association (APHA), 1998. Standard Methods for theExamination of Water and Wastewater. American Public Health Association,Washington, DC.

Agrawal, S.C., 1999. Limnology. A.P.H. Pub. Corp., New Delhi.B-Béres, V., Török, P., Kókai, Z., Krasznai, E.T., Tóthmérész, B., Bácsi, I., 2014.Ecological diatom guilds are useful but not sensitive enough as indicators ofextremely changing water regimes. Hydrobiologia 738 , 191-204.

Bayona, Y., Roucaute, M., Cailleaud, K., Lagadic, L., Bassères, A., Caquet, T., 2014.Structural and biological trait responses of diatom assemblages to organicchemicals in outdoor flowthrough mesocosms. Environ. Pollut. 192, 186-195.

Bennion, H., Sayer, C.D., Tibby, J., Carrick, H.J., 2010. Diatoms as indicators ofenvironmental change in shallow lakes. In: The Diatoms: Applications for theEnvironmental and Earth Sciences. Cambridge University Press, Cambridge, pp.152-173.

Berthon, V., Bouchez, A., Rimet, F., 2011. Using diatom life-forms and ecologicalguilds to assess organic pollution and trophic level in rivers: a case study ofrivers in south-eastern France. Hydrobiologia 673, 259-271. 
Bhattacharyya, P., Volcani, B.E., 1980. Sodium-dependent silicate transport in theapochlorotic marine diatom Nitzschia alba. Proc. Natl. Acad. Sci. U. S. A. 77,6386-6390.

Black, J.L., 2008. Holocene Climate Change in South-central Iceland: A Multi-proxyLacustrine Record from Glacial Lake Hvitarvatn. University of Colorado,Boulder.

Blanco, S., Ector, L., Bécares, E., 2004. Epiphytic diatoms as water quality indicatorsin Spanish shallow lakes. Vie Milieu 54 (2-3), 71-79.

Blinn, D.W., 1993. Diatom community structure along physicochemical gradientsin Saline Lakes. Ecology 74, 1246.

Brooks, R.T., 2009. Potential impacts of global climate change on the hydrology andecology of ephemeral freshwater systems of the forests of the northeasternUnited States. Clim. Change 95, 469-483.

Caramujo, M.-J., Boavida, M.-J., 2010. Biological diversity of copepods andcladocerans in Mediterranean temporary ponds under periods of contrastingrainfall. J. Limnol. 69, 64-75.

Cohn, S.A., Disparti, N.C., 1994. Environmental factors influencing diatom cellmotility. J. Phycol. 30, 818-828.

Dickens, C.W., Graham, P.M., 2002. The South African Scoring System (SASS)version 5 rapid bioassessment method for rivers. Afr. J. Aquat. Sci. 27, 1-10.

Gaiser, E., Rühland, K., 2010. Diatoms as indicators of environmental change inwetlands and peatlands. In: The Diatoms: Applications for the Environmentaland Earth Sciences. Cambridge University Press, Cambridge, pp. 473-496.

Gasse, F., Talling, J.F., Kilham, P., 1983. Diatom assemblages in East Africa:classification, distribution and ecology. Rev. Hydrobiol. Trop. 16, 3-34.

Gasse, F., 1986. East African Diatoms: Taxonomy, Ecological Distribution,Bibliotheca Diatomologica. J. Cramer, Berlin.

Gasse, F., Juggins, S., Khelifa, L.B., 1995. Diatom-based transfer functions forinferring past hydrochemical characteristics of African lakes. Palaeogeogr.Palaeoclimatol. Palaeoecol. 117, 31-54.

Goldenberg Vilar, A., van Dam, H., Vonk, J.A., van der Geest, H.G., Admiraal, W.,2014. Typology of diatom communities in the Dutch delta: recognizingpatterns of environmental drivers in nutrient rich ditches. Ecol. Indic. 45,561-569.

Gottschalk, S., Kahlert, M., 2012. Shifts in taxonomical and guild composition oflittoral diatom assemblages along environmental gradients. Hydrobiologia694, 41-56. 
Gregory-Eaves, I., Smol, J.P., Finney, B.P., Edwards, M.E., 1999. Diatom-basedtransfer functions for inferring past climatic and environmental changes inAlaska. Arct. Antarct. Alp. Res., 353-365.

Holm, S., 1979. A simple sequentially rejective multiple test procedure. Scand. J.Stat. 6, 6570.

Köster, D., Racca, J.M.J., Pienitz, R., 2004. Diatom-based inference models andreconstructions revisited: methods and transformations. J. Paleolimnol. 32,233-246.

Kelly, M.G., Juggins, S., Bennion, H., Burgess, A., Yallop, M., Hirst, H., King, L.,Jamieson, J., Guthrie, R., Rippey, B., 2007. Use of Diatoms for EvaluatingEcological Status in UK Freshwaters. Environment Agency Science Report No.SC030103. Environment Agency, Bristol.

King, L., Clarke, G., Bennion, H., Kelly, M., Yallop, M., 2006. Recommendations forsampling littoral diatoms in lakes for ecological status assessments. J. Appl.Phycol. 18, 15-25.

Krammer, K., Lange-Bertalot, H., 1986-1991. Bacillariaceae. In: Ettl, H., Gerloff, J.,Heynig, H., Mollenhauer, D. (Eds.), Susswasserflora von Mitteleuropa.Spektrum Akademischer Verlag, Heidelberg, pp. 1-2458.Lane, C.R., Brown, M.T., 2007. Diatoms as indicators of isolated herbaceous wetlandcondition in Florida, USA. Ecol. Indic. 7, 521-540.

Lane, C.R., 2007. Assessment of isolated wetland condition in Florida usingepiphytic diatoms at genus, species, and subspecies taxonomic resolution.EcoHealth 4, 219-230.

Lange, K., Liess, A., Piggott, J.J., Townsend, C.R., Matthaei, C.D., 2011. Light, nutrientsand grazing interact to determine stream diatom community composition andfunctional group structure Diatom responses to light, nutrients and grazing.Freshw. Biol. 56, 264-278.

Lange, K., Townsend, C.R., Matthaei, C.D., 2016. A trait-based framework for streamalgal communities. Ecol. Evol. 6, 23-36.

Lange-Bertalot, H., Podzorski, A., Lange-Bertalot, H., 2001. Navicula Sensu Stricto,10 Genera Separated from Navicula Sensu Lato, Frustulia Diatoms of Europe.Gantner, Ruggell/Liechtenstein.

Lange-Bertalot, H. (Ed), 2000-2002. Diatoms of Europe. Diatoms of the EuropeanInland Waters and Comparable Habitats. Vols. I-IV, Diatoms of Europe. A. R. G.Gantner Verlag K. G: Ruggell.Lavoie, I., Lento, J., Morin, A., 2010. Inadequacy of size distributions of streambenthic diatoms for environmental monitoring. J. N. Am. Benthol. Soc. 29,586-601.

Leira, M., Chen, G., Dalton, C., Irvine, K., Taylor, D., 2009. Patterns in freshwaterdiatom taxonomic distinctness along an eutrophication gradient. Freshw. Biol.54, 1-14. 
Leira, M., Filippi, M.L., Cantonati, M., 2015. Diatom community response toextreme waterlevel fluctuations in two Alpine lakes: a core case study. J.Paleolimnol. 53, 289-307.

Luttenton, M.L., Vansteenburg, J.B., Rada, R.G., 1986. Phycoperiphyton in selectedreaches of the Upper Mississippi River: community composition, architecture,and productivity. Hydrobiologia 136, 31-45.

Masmoudi, S., Nguyen-Deroche, N., Caruso, A., Ayadi, H., Morant-Manceau, A.,Tremblin, G., Bertrand, Martine, Schoefs, B., 2013. Cadmium, copper, sodiumand zinc effects on diatoms: from heaven to hell-a review. Cryptogam. Algol.34, 185-225.

Morin, S., Bottin, M., Mazzella, N., Macary, F., Delmas, F., Winterton, P., Coste, M.,2009. Linking diatom community structure to pesticide input as evaluatedthrough a spatial contamination potential (Phytopixal): a case study in theNeste river system (South-West France). Aquat. Toxicol. 94, 28-39.

Niemistö, J., Holmroos, H., Pekcan-Hekim, Z., Horppila, J., 2008. Interactionsbetween sediment resuspension and sediment quality decrease the TN:TPratio in a shallow lake. Limnol. Oceanogr. 53, 2407-2415.

Passy, S.I., Larson, C.A., 2011. Succession in stream biofilms is an environmentallydriven gradient of stress tolerance. Microb. Ecol. 62, 414-424.

Passy, S.I., 2007a. Diatom ecological guilds display distinct and predictablebehavior along nutrient and disturbance gradients in running waters. Aquat.Bot. 86, 171-178.

Passy, S.I., 2007b. Community analysis in stream biomonitoring: what we measureand what we don't. Environ. Monit. Assess. 127, 409-417.

Patrick, R., Reimer, C.W., 1966. The Diatoms of the United States, Exclusive ofAlaska and Hawaii, Monograph (Academy of Natural Sciences of Philadelphia).Academy of Natural Sciences of Philadelphia.

Peterson, C.G., Stevenson, R.J., 1992. Resistance and resilience of Lotic AlgalCommunities: importance of disturbance timing and current. Ecology 73, 1445.

Potapova, M., Charles, D.F., 2003a. Distribution of benthic diatoms in US rivers inrelation to conductivity and ionic composition. Freshw. Biol. 48, 1311-1328.

Potapova, M., Charles, D.F., 2003b. Distribution of benthic diatoms in US rivers inrelation to conductivity and ionic composition. Freshw. Biol. 48, 1311-1328.

Prechtl, J., 2004. Intracellular spheroid bodies of Rhopalodia gibba havenitrogen-fixing apparatus of Cyanobacterial origin. Mol. Biol. Evol. 21,1477-1481.

Reichardt, E., Lange-Bertalot, H. (Eds.), 1999. Koeltz Scientific Books, Königstein. 
Reichardt, E., 2015. Gomphonema gracile Ehrenberg sensu stricto et sensu auct.(Bacillariophyceae): a taxonomic revision. Nova Hedwig. 101, 367-393.

Riato, L., Van Ginkel, C., Taylor, J.C., 2014. Zooplankton and diatoms of temporaryand permanent freshwater pans in the Mpumalanga Highveld region, SouthAfrica. Afr. Zool. 49, 113-127.

Rimet, F., Bouchez, A., 2011. Use of diatom life-forms and ecological guilds toassess pesticide contamination in rivers: lotic mesocosm approaches. Ecol.Indic. 11, 489-499.

Rimet, F., Bouchez, A., 2012a. Biomonitoring river diatoms: implications oftaxonomic resolution. Ecol. Indic. 15, 92-99.

Rimet, F., Bouchez, A., 2012b. Life-forms, cell-sizes and ecological guilds of diatomsin European rivers. Knowl. Manag. Aquat. Ecosyst., 01.

Rimet, F., Ector, L., Cauchie, H.-M., Hoffmann, L., 2009. Changes indiatom-dominated biofilms during simulated improvements in water quality:implications for diatom-based monitoring in rivers. Eur. J. Phycol. 44, 567-577.

Rose, D., Cox, E.J., 2014. What constitutes Gomphonema parvulum? Long-termculture studies show that some varieties of $\mathrm{G}$. parvulum belong with otherGomphonema species. Plant Ecol. Evol. 147, 366-373.

Rumeau, A., Coste, M., 1988. Initiation à la systematique des diatomées d'eaudouce pour I'utilisation pratique d'un indice diatomique générique. Bull. Fr.Peche Piscic. 309, 1-69.

Saros, J.E., Fritz, S.C., 2000. Nutrients as a link between ionicconcentration/composition and diatom distributions in saline lakes. J.Paleolimnol. 23, 449-453.

Schoeman, F.R., Archibald, R.E.M., 1976. The Diatom Flora of Southern Africa.National Institute for Water Research, CSIR Special Report WAT 50, Pretoria,South Africa.

Stenger-Kovács, C., Buczkó, K., Hajnal, É., Padisák, J., 2007. Epiphytic, littoraldiatoms as bioindicators of shallow lake trophic status: Trophic Diatom Indexfor Lakes (TDIL) developed in Hungary. Hydrobiologia 589, 141-154.

Stenger-Kovács, C., Lengyel, E., Crossetti, L.O., Üveges, V., Padisák, J., 2013.

Diatomecological guilds as indicators of temporally changing stressors anddisturbances in the small Torna-stream, Hungary. Ecol. Indic. 24, 138-147.

Stokes, P.M., 1986. Ecological effects of acidification on primary producers inaquatic systems. Water Air Soil Pollut. 30, 421-438. 
Tapolczai, K., Bouchez, A., Stenger-Kovács, C., Padisák, J., Rimet, F., 2016.Trait-based ecological classifications for benthic algae: review andperspectives. Hydrobiologia 776, 117.

Taylor, J.C., de la Rey, P.A., van Rensburg, L., 2005. Recommendations for thecollection, preparation and enumeration of diatoms from riverine habitats forwater quality monitoring in South Africa. Afr. J. Aquat. Sci. 30, 65-75.

Ter Braak, C.J.F., 'Smilauer, P., 1998. CANOCO Reference Manual and User's Guide toCanoco for Windows: Software for Canonical Community Ordination (version4). Centre for Biometry.

Ter Braak, C., `Smilauer, P., 2002. CANOCO reference manual and CanoDraw forWindows user's guide: software for canonical community ordination (version4.5). Microcomputer power, Itaca www.canoco.com.

Timoney, K., Zoltai, S.C., Goldsborough, L.G., 1997. Boreal diatom ponds: a rarewetland associated with nesting whooping cranes. Wetlands $17,539-551$.

U.S. EPA, 2002. Methods for Evaluating Wetland Condition: Using Algae to AssessEnvironmental Conditions in Wetlands.

Vázquez, G., Caballero, M., 2013. The structure and species composition of thediatom communities in tropical volcanic lakes of eastern Mexico. Diatom Res.28, 77-91.

Zimba, P.V., Hopson, M.S., 1997. Quantification of epiphyte removal efficiency fromsubmersed aquatic plants. Aquat. Bot. 58, 173-179

Zotarelli, L., Dukes, M.D., Romero, C.C., Migliaccio, K.W., Morgan, K.T., 2010. Step bystep calculation of the Penman-Monteith Evapotranspiration (FAO-56Method). Inst. Food Agric. Sci. Univ. Fla. 


\section{Appendix A. Supplementary data}

\section{Appendix S1}

Description of physical characteristics of sites and local climatology

The study area is situated within the Highveld climate region of South Africa. Here monthly means of daily maximum temperature range from 28 to $30^{\circ} \mathrm{C}$ in the summer months

(December to March), while minimum temperatures in the same months are between 12 and $16^{\circ} \mathrm{C}$ (Schulze, 1997). More than half of the precipitation occurs between October and March (with a maximum in January) (Dyson, 2009). Depressional wetlands in this area are typically ephemeral and tend to be fully inundated during summer and dry out in winter, where water loss is mostly attributable to evaporation (Ferreira, 2012). From January to March 2011, the late summer rainfall amounted to 447mm (Agricultural Research Council (ARC), Pretoria) which exceeded the average 309mm over the same period (Dyson, 2009). Random periods of above-average rainfall can affect the duration of inundation in ephemeral wetlands (Henry et al., 2016). This phenomenon was observed in all three study sites which remained inundated throughout winter (May-August) in 2011.

By the end of the sampling period in September 2012, S1 almost dried out completely and S2 and S3 were reduced to two shallow pools (July - Sept 2012). When full, S1 and S3 had a surface area of $59,300 \mathrm{~m}^{2}$ and $57,900 \mathrm{~m}^{2}$, with a maximum depth of 84.3 and $99.8 \mathrm{~cm}$, and a mean depth of $46.8 \mathrm{~cm}$ and $66.6 \mathrm{~cm}$, respectively, while $\mathrm{S} 2$ was the largest of the sites which had a surface area of $202,600 \mathrm{~m}^{2}$, a maximum depth of $114.4 \mathrm{~cm}$ and a mean depth of $70.7 \mathrm{~cm}$. S3 was similar in surface area to $\mathrm{S} 1$ but as its basin profile was more concave, it had a greater depth than $\mathrm{S} 1$ and therefore remained inundated throughout the study. S2 also remained inundated throughout the study period as it had a similar depth to S3 with a large surface area. 
The land-use in the catchment is mostly dryland cultivation (between 69-74\%) and natural grassland (18-19\%). Human-induced disturbance to wildlife was low as suggested by the presence of African bullfrog Pyxicephalus adspersus and fairy shrimp Anostraca sp.

Table S1 Mean values, \pm standard deviation and ranges of the physical and chemical variables of the study sites used in the analyses, where $n=21$ for each site.

\begin{tabular}{|c|c|c|c|c|c|c|c|c|c|}
\hline & \multicolumn{3}{|c|}{ S1 } & \multicolumn{3}{|c|}{ S2 } & \multicolumn{3}{|c|}{ S3 } \\
\hline & Mean & Min & $\operatorname{Max}$ & Mean & Min & $\operatorname{Max}$ & Mean & Min & $\operatorname{Max}$ \\
\hline ETo (mm) & $3.2 \pm 0.9$ & 1.9 & 4.8 & $3.2 \pm 0.9$ & 1.9 & 4.8 & $3.2 \pm 0.9$ & 1.9 & 4.8 \\
\hline Depth (cm) & $46.8 \pm 24.5$ & 2.1 & 84.3 & $70.7 \pm 28.6$ & 27.8 & 114.4 & $66.6 \pm 21.9$ & 23 & 99.8 \\
\hline Temperature $\left({ }^{\circ} \mathrm{C}\right)$ & $16 \pm 6.3$ & 6.9 & 27.6 & $19.5 \pm 6.2$ & 11.6 & 30.1 & $19.8 \pm 7$ & 11 & 32.1 \\
\hline $\mathrm{DO}(\mathrm{ppm})$ & $2.4 \pm 2.4$ & 0 & 9.3 & $5.2 \pm 8.6$ & 0 & 42.2 & $5.2 \pm 5.6$ & 1 & 28.5 \\
\hline $\mathrm{BOD}^{\mathrm{a}}$ & $21 \pm 31.5$ & 5 & 126 & $22.3 \pm 49.7$ & 5 & 228 & $8.9 \pm 11.5$ & 5 & 56 \\
\hline $\mathrm{DOC}^{\mathrm{a}}$ & $23.5 \pm 18.5$ & 4.3 & 79 & $13 \pm 16.4$ & 2.8 & 78 & $14.3 \pm 6.9$ & 4.9 & 30 \\
\hline $\mathrm{pH}$ & $7.2 \pm 0.6$ & 6.3 & 8.6 & $7.5 \pm 0.5$ & 6.9 & 8.6 & $7.4 \pm 0.6$ & 6.7 & 8.7 \\
\hline Conductivity $\left(\mu \mathrm{Scm}^{-1}\right)$ & $154.5 \pm 98.2$ & 59 & 460 & $155.8 \pm 95.8$ & 50 & 438 & $147 \pm 59.9$ & 76 & 313 \\
\hline Alkalinity $^{a}$ & $68.2 \pm 37.5$ & 28 & 188 & $85.9 \pm 56.4$ & 44 & 284 & $69.5 \pm 27.1$ & 40 & 152 \\
\hline $\mathrm{Ca}^{2+\mathrm{a}}$ & $12.3 \pm 6.1$ & 6 & 35 & $20.9 \pm 15.7$ & 9 & 82 & $12.8 \pm 5$ & 7 & 30 \\
\hline $\mathrm{Mg}^{2+\mathrm{a}}$ & $6.8 \pm 3.2$ & 2 & 18 & $7.4 \pm 5.7$ & 3 & 28 & $7.5 \pm 3.5$ & 3 & 14 \\
\hline $\mathrm{Na}^{+\mathrm{a}}$ & $12.6 \pm 7.2$ & 1 & 36 & $2.8 \pm 2.2$ & 1 & 10 & $7.7 \pm 4.8$ & 2 & 20 \\
\hline $\mathrm{K}^{+\mathrm{a}}$ & $5.9 \pm 10.1$ & 0.5 & 35 & $6.9 \pm 6.6$ & 3.3 & 31 & $5.1 \pm 3.5$ & 1.1 & 15.3 \\
\hline $\mathrm{SO}_{4}^{2-\mathrm{a}}$ & $2.5 \pm 0.1$ & 2.5 & 3 & $2.4 \pm 0.3$ & 1 & 2.5 & $2.9 \pm 2.1$ & 1 & 12 \\
\hline $\mathrm{Cl}^{-\mathrm{a}}$ & $7.6 \pm 5.3$ & 2.5 & 22 & $3.6 \pm 2.8$ & 2.5 & 13 & $6 \pm 2.7$ & 2.5 & 11 \\
\hline Turbidity (NTU) & $154.4 \pm 554.7$ & 3.9 & 2565 & $98.4 \pm 369.1$ & 1.8 & 1707 & $19.8 \pm 23.3$ & 6.8 & 115 \\
\hline $\mathrm{TSS}^{\mathrm{a}}$ & $310.5 \pm 767.6$ & 0.5 & 3136 & $205.9 \pm 717.2$ & 0.5 & 3322 & $45.5 \pm 67.3$ & 0.5 & 296 \\
\hline $\mathrm{N}-\mathrm{NO}_{3}{ }^{-}$and $\mathrm{N}-\mathrm{NO}_{2}{ }^{-\mathrm{a}}$ & $0.5 \pm 0.9$ & 0.1 & 3.3 & $0.2 \pm 0.1$ & 0.1 & 0.5 & $0.3 \pm 0.4$ & 0.1 & 1.6 \\
\hline $\mathrm{TKN}^{\mathrm{a}}$ & $8.7 \pm 16.7$ & 0.1 & 67 & $7 \pm 19.7$ & 0.1 & 92 & $2.9 \pm 3.1$ & 0.3 & 15 \\
\hline Total phosphate & $1.2 \pm 2.3$ & 0.1 & 9.6 & $0.9 \pm 1.9$ & 0.1 & 8.5 & $0.4 \pm 0.6$ & 0.1 & 2.8 \\
\hline Ortho-phosphate ${ }^{a}$ & $0.1 \pm 0$ & 0.1 & 0.1 & $0.1 \pm 0$ & 0.1 & 0.2 & $0.1 \pm 0.2$ & 0.1 & 1 \\
\hline Phosphorus ${ }^{\mathrm{a}}$ & $0.2 \pm 0.4$ & 0.01 & 1.8 & $0.1 \pm 0.3$ & 0.01 & 1.6 & $0.1 \pm 0.01$ & 0.01 & 0.4 \\
\hline $\mathrm{NH}_{4}{ }^{+\mathrm{a}}$ & $0.3 \pm 0.4$ & 0.1 & 1.5 & $0.2 \pm 0.3$ & 0.1 & 1.6 & $0.2 \pm 0.1$ & 0.1 & 0.4 \\
\hline
\end{tabular}

${ }^{\mathrm{a}} \mathrm{mgL}^{-1}$. Alkalinity as $\mathrm{CaCO}_{3}$. 


\section{Supplementary References}

Dyson, L.L., 2009. Heavy daily-rainfall characteristics over the Gauteng Province. Water SA $35,627-638$.

Ferreira, M., 2012. The development of methods to assess the ecological integrity of perennial pans. PhD thesis. Johannesburg, South Africa: University of Johannesburg.

Henry, D.A.W., Ament, J.M., Cumming, G.S., 2016. Exploring the environmental drivers of waterfowl movement in arid landscapes using first-passage time analysis. Mov. Ecol. 4. doi:10.1186/s40462-016-0073-x

Schulze, R.E., 1997. South African atlas of agrohydrology and climatology, TT82/96. Water Research Commission, Pretoria, South Africa. 